\title{
Pembelajaran Berbasis Teknologi Model Drill and Practice untuk Meningkatkan Hasil Belajar pada Pelajaran Matematika di Sekolah Dasar
}

\author{
Khoirunisa $^{1}$, Andi Prastowo ${ }^{2}$, Siti Fatimah ${ }^{3}$ \\ Universitas Islam Negeri Sunan Kalijaga Yogyakarta \\ E-mail:21204081011@student.uin-suka.ac.id, andi.prastowo@uin-suka.ac.id, \\ 21204081016@student.uin-suka.ac.id
}

\begin{abstract}
Article Info Abstract

Article History

Received: 2021-11-20

Revised: 2021-12-15

Published: 2022-01-03

This study aims to see: 1) whether the use of technology-based learning using the drill and practice model is able to improve learning outcomes and 2) how to apply the drill and practice model to learning mathematics in the learning process. The research method used in this study is a qualitative method and the approach used is library research or library research. The data obtained in this study used data collection

Keywords: Learning; Technology; Drill and practice; Mathematic. techniques with documentation, namely looking for data in the form of articles from journals about technology-based learning with drill and practice models in learning mathematics and in elementary schools. by using several references to scientific articles that support this literature research, the results of this study explain that of the 6 research articles the analysis shows that the analysis of the use of the drill and practice model is able to have a positive impact which can be seen from the increased mathematics learning outcomes in the use of this model in learning.
\end{abstract}

\begin{tabular}{l}
\hline Artikel Info \\
\hline Sejarah Artikel \\
Diterima: $2021-11-20$ \\
Direvisi: $2021-12-15$ \\
Dipublikasi: $2022-01-03$
\end{tabular}

Kata kunci:

Pembelajaran; Teknologi;

Drill and practice; Matematika. \begin{abstract}
Abstrak
Penelitian ini bertujuan untuk melihat: 1) apakah penggunaan pembelajaran berbasis
teknologi model drill and practice ini mampu meningkatkan hasil belajar serta 2)
bagaimana implementasi model drill and practice pada pembelajaran matematika
dalam proes pembelajaran. metode penelitian yang digunakan dalam penelitian ini
merupakan metode kualitatif dan pendekatan yang digunakan yaitu studi kepustakaan
atau library research. Data yang didapatkan dalam penelitian ini menggunakan teknik
pengumuplan data dengan dokumentasi yaitu mencari data dalam bentuk artikel dari
jurnal tentang pembelajaran berbasis teknologi model drill and practice dalam
pembelajaran matematika maupun di sekolah dasar. dengan menggunakan beberapa
referensi artikel ilmiah yang menunjang penelitian kepustakaan ini, hasil dari
penelitian ini menjelaskan bahwa dari analisis 6 artikel yang peneliti analisis
menunjukkan yaitu penggunaan model drill and practice ini mampu memberikan
dampak positif terlihat dari hasil belajar matematika yang meningkat pada pengunaan
model ini dalam pembelajaran.
\end{abstract}
\section{PENDAHULUAN}

Guru memberi pengaruh penting bagi pendidikan siswa serta kedudukan yang penting pada pendidikan di sekolah, sebagai seorang pendidik seorang guru diharuskan untuk selalu kreatif karena ini sangat memberi pengaruh yang besar dalam proses pelajaran disekolah, salah satunya bisa dengan penggunaan model, strategi maupun metode pelajaran sangat diperlukan supaya siswa tidak merasa kejenuhan disebabkan oleh yang dipelajari ditambah lagi dengan pelajaran yang sulit dimengerti salah satunya pada pelajaran matematika, pelajaran matematika di sekolah dasar yaitu suatu pembahasan amat menarik untuk mengutarakan sebab terdapat variasi ciri-ciri tertentu antara prinsip anak dengan prinsip matematika. Maka dari itu dibutuhkan adanya penghubung yang bisa menetralkan perbedaan maupun pertenta- ngan tersebut. Di usia ini anak sekolah dasar tengah memasuki fase perkembangan pada tingkat berpikirnya. Disebabkan oleh proses berpikir anak cenderung belum formal, terkadang peserta didik di sekolah dasar pada kelaskelas rendah bukan tidak mungkin setengah dari mereka cara berpikirnya dalam keadaan di tahapan pra konkret. Selain itu Manfaatnya juga sangat terlihat yaitu pada pelajaran matematika bisa membentuk cara berpikir orang yang mempelajarinya menjadi cara berpikir matematis dan terstruktur, valid, tepat, serta penuh ketelitian. Matematika bagi siswa sangat bermanfaat bagi hidup dalam lingkungan masyarakat, untuk mengembangkan pola pikirnya, serta bisa mempelajari pengeta-huan-pengetahuan yang selanjutnya. (Wahyu, Putra, Indriani, \& Info, 2017) Namun permasa-lahan yang terjadi di tahap pembelajaran di kelas siswa tetap ada saja 
kendala yang sering dialami pada tahap pembelajaran Matematika. biasanya pada cara penyampaian materi dalam proses pembelajaran masih bersifat tradisional dan konvensional, membuat siswa sedikit yang mengerti dalam pemahaman uuntuk materi yang telah dijelaskan membuat pengaruh terhadap hasil pembelajaran yang menjadi rendah. Oleh sebab itu model belajar yang masih sifatnya berpusat pada guru meski diberikan perubahan sehingga bukan tenaga pendidik saja yang berperan aktif dalam tahap pembelajaran, akan tetapi juga perlu dilaksanakan sendiri oleh peserta didik itu. Pada permasalahan yang terjadi, maka perlunya bermacam cara pada peningkatkan tahap belajar mengajar Matema-tika di sekolah dasar. Dalam menyiapkan materi pelajaran maupun pelaksanaan proses pembela-jaran, seorang guru meski mempunyai tepatnya strategi belajar mengajar diharapkan mampu mengelola kegiatan pembelajaran dengan kreatif serta memperkenalkan inovasi terbaru.

Kemajuan teknologi informasi dan komunikasi memberi pengaruh besar untuk bermacam kehidupan manusia, salah satu contohnya pada bagian pendidikan maupun pembelajaran. Pendidikan perlu memikirkan serta melakukan pembelajaran harus tepat pada kebutuhan siswa serta sebagai wadah dalam pada tahap pembelajaran yang memiliki arti, menarik, dan mengikuti perkembangan ilmu pengetahuan teknologi, pada tahap ini mampu membantu peserta didik dalam peningkatan prestasi dalam belajar. (Adiwisastra, 2015) untuk tahap pembelajaran, komputer sudah diberi keterlibatan sebagai alat pembelajaran. Secara umum, multimedia yaitu media yang digunakan untuk menyampaikan informasi yang memberi campuran terhadap bagain teks, gerak, gambar, animasi video serta suara. Multimedia berbasis komputer meliputi penyampaian komputer dari bermacam gambaran media (contohnya teks, gambar, suara dan video) agar memberi penyampaian informasi dalam bentuk linear atau non linear. (Nasution Asrin, 2021) pembelajaran matematika di SD bertujuan yaitu untuk peserta didik dapat berkemampuan pada konsep-konsep matematika. Depdiknas (2006) dari Permendiknas No.22 mengemukakan pendapat mengenai standar isi memberi pernyataan pembelajaran matematika di SD/MI, SMP/MTs, SMA/MA, dan SMK/MAK memiliki tujuan yaitu supaya siswa: a. pemahaman terhadap konsep matematika, menunjukkan hubungan dengan bagian penerapan konsep atau algoritma, dengan mudah, tepat, efektif, serta akurat, untuk menyelesaikan masalah. b. Menyampaikan pandangan dengan simbol, tabel, diagram, maupun media lain guna memperjelas kondisi maupun masalah. c. Mempunyai sikap menghargai pentingnya matematika bagi kehidupan, ialah mempunyai rasa keinginan untuk mengetahui, simpati, dan keinginan dalam mempelajari matematika, perilaku tidak malasmalasan serta percaya diri dalam pemecahan masalah. Untuk itu kita mengetahui tentang tujuan serta kedudukan mata pelajaran matematika ini diperlukan sebuah pembelajaran matematika yang Efektif dan berarti untuk peserta didik. Oleh sebab itu peserta didik meski mengerti dan menguasai matematika kemudian bermacam keahlian serta diharapkan bisa mencapai dengan baik serta ideal. Namun masalah utama yang terjadi pada dunia pendidikan Indonesia saat ini adalah kecilnya kualitas serta keberhasilan belajar siswa di sekolah. (Surya, 2017)

Matlin memberi pendapat tentang belajar adalah suatu transformasi sifat maupun sikap yang secara keseluruhan dengan waktu yang lama, merupakan perolehan dari pengalaman. Berikutnya yaitu pada hubungan lingkungan sekolah, belajar merupakan suatu merupakan tahap upaya yang dilaksanakan peserta didik agar mendapatkan bentuk transformasi dari sikap dengan menyeluruh, ini merupakan hasil yang didapati sebagai sebuah pengalaman peserta didik tersebut hubungan dengan lingkungannya (Akbar \& Hawadi, 2004), dengan begitu bisa diartikan tentang hasil belajar yaitu evaluasi diri siswa maupun transformasi yang bisa dilihat, menetapkan, dan ternilai pada kemampuan maupun kinerja yang sudah dilalui oleh siswa merupakan hasil dari pengalaman belajar. (Nurhasanah \& Sobandi, 2016)

Hasil belajar siswa adalah sebuah tujuan dari proses pembelajaran di sekolah, oleh karenanya sebagai guru harus tahu, bagaimana menerapkan bermacam metode mengajar yang, laleu diaplikasikan dalam proses pengajaran kepada siswa di kelas. Pada pengaplikasian setiap metode ini diharapkan mampu mendapatkan prestasi atau hasil belajar siswa yang tinggi, sebagai guru kita diharuskan agar membimbing dan mengajarkan peserta didik pada penggunaan metode pembelajaran yang tepat pada kebutuhan belajar siswa di kelas. Trianto (2010) mengatakan tentang model pembelajaran merupakansebuah perencanaan mmaupun pola yang digunakan sebagai petunjuk untuk merencanakan sebuah pembeelajaran di kelas ataupun pembelajaran 
tutorial. Dari Pupuh dan Sobry S (2010) memberi pendapat tentang metode, dengan menggunakan metode yang tepat akan menghasilkan keefektifan dalam mencapai tujuan pembelajaran yang diajarkan. Dari metode yang tepat bisa dikatakan bahwa mampu mencapai hasil belajar siswa yang tinggi serta berkualitas, untuk sebuah pembelajaran yang berkualitas sebagai tenaga pendidik perlunya kemampuan guru pada penerapan metode pembelajaran yang harus tepat dengan kebutuhan dalam kelas, metode yang tidak tepat pada implementasi sebuah pelajaran dapat menurunkan kualitas tahap pembelajaran tersebut, maka dari itu perlunya perbaikan dan peningkatan hasil belajar siswa di sekolah mampu dilangsungkan dengan adanya penggunaan metode pembelajaran yang cocok oleh guru. (Nasution, 2017)

Model pembelajaran Drill and Practice sebuah cara pegajaran pada pengaplikasianya dikerjakan secara berulang-ulang agar menghasilkan keterampilan, dan perlunya mengingat secara matematis, Pada Metode Drill and Practice ini untuk implementasinya pada pembelajaran materi hitungan, bahasa asing serta untuk meningkatkan kumpulan kata yaitu bagian dari suatu bahasa tertentu, (vocabulary). Dengan penggunaanMetode Drill and Practice ini mempunyai fase dalam pembelajaran mencakup: 1. Mempertunjukkan pengetahuan, serta Skill 2. Mendapatkan tujuan-tujuan, 3. Mengadakan latihan-latihan yang harus adanya pembimbi-ngan, 4. Memeriksa pengertian dan memberi tanggapan balik, 5. Serta memberikan kembali latihan lanjutan.( McDonough, Sharon K. 2005). (Ismanto \& Cynthia, 2017)

Pada penggunaan Multimedia pembelajaran model drill and practice ini sangat tepat bagi karakteristik maupun kebutuhan siswa yaitu dilaksanakan pemberian sebuah. (Lintang, Astuti, \& Tanjungpura, 2021) pada pelaksanaan dengan model drill and practice ini, hendaklah guru perlupeninjauan persiapan dari guru yang akan mengajar, siswa serta semua sarana yang ada. Berikut tahap-tahap dalam penggunaan model drill and practice terdapat beberapa sebagai berikut 1) tahap membuka dalam proses pelajaran, tindakan dalam membuka ada hal-hal yang meski di sermati bagi guru yaitu menjelaskan terlebih dahulu tujuan yang meski diperoleh, 2) tindakan pelaksanaannya yaitu: a) mengawali latihan dengan soal latihan yang sederhana terlebih dahulu, b) membuat suasana dalam keadaan yang menarik, c) membuat siswa ingin ikut serta terlibat, d) membagikan momen pada peserta didik membiasakan serta berkarya. 3) pada tahap penutupan, tenaga pendidik perlu memberikan tekad kepada siswa dalam melaksanakan latihan secara bertahap sehingga latihan yang telah diberikan melekat.

Pada jurnal Wachid Nugroho dengan judul (Pendekatan Inquiry Model Drill And Practice Berbasis Aplikasi Moodle Berbantuan Video Youtube Untuk Meningkatkan Aktivitas Dan Hasil Belajar Peserta Didik Pada Materi Limit Fungsi) hasil dari penelitian ini menunjukkan pada analisis Data angket, lembar pengamatan, dan penilaian belajar memakai deskripsi komparatif secara kuantitatif dan kualitatif untuk mendapatkan hasil peningkatan aktivititas dan hasil belajar pada siswa. Hasil penelitian ini memdapatkan peningkatan golongan aktif peserta didik sebesar $8,83 \%$ dari jangkauan $79,41 \%$ di siklus pertama meningkat ke $88,24 \%$ di siklus kedua. sementara nilai rerata kelas mengalami peningkatan sebesar 62,90 dari hasil 850,00 di siklus pertama mengalami peningkatan menjadi 912,90 di siklus 2. Ketuntasan kelas di siklus pertama mencapai $67,65 \%$ meningkat $23,53 \%$ menjadi 91,18\% disiklus kedua. dari hasil penelitian ini implementasi pendekatan inquiry model drill and practice berbasis aplikasi moodle berbantuan video youtube mampu meningkatkan aktivitas dan hasil belajar siswa pada materi limit fungsi aljabar.(Nugroho Wachid, 2020)

Dari hasil penelitian diatas pada pembelajaran matematika pada penggunaan model drill and practice berbasis teknologi dalam proses pembelajaran di sekolah menduduki tempat penting terhadap hasil belajar siswa, penggunaan model serta metode yang cocok menjadi alasan yang pentingnya untuk penggunaannya dalam pembelajaran dapat dilihat dari hasil peneltian jurnal oleh Wachid Nugroho diatas menunjukkan bahwa pada Ketuntasan kelas disiklus pertama mendapatkan 67,65\% meningkat 23,53\% menjadi $91,18 \%$ di siklus kedua.

Menurut hasil Dari penelitian oleh Farhanah, Artikel penelitian dengan judul tentang penggunaan metode drill terhadap hasil belajar matematika hitung campuran kelas III SDN 24 Pontianak. Pada penelitian ini dengan tujuan agar menghasilkan untuk dalam menerapkan pengimplikasian metode drill dalam meningkatkan kemampuan peserta didik pada operasi hitung campuran di kelas III SDN 24 Pontianak. Jenis dari pada penelitian ini memakai penelitian tindakan kelas (PTK). Pada PTK ini golongan pada penelitian kualitatif dikarenakan saat data dianalisis digunakan pendekatan kualitatif untuk 
penjelasan pada kenyataan serta mendapatkan penjelasan memenuhi keyataan yang telah terjadi. pada penelitian yang telah dilaksanakan adalah 51,81. Hasil analisis setelah dilakukan penelitian sampai siklus kedua nilai rata-rata peserta didik mengalami peninggkatan yaitu 71,81. bisa disimpulkan peneliti yaitu adanya peningkatan hasil belajar dengan dalam penggunaan metode drill pada materi matematika hitung campuran di kelas III SDN 24 Pontianak. (Farhanah, 2012)

Berdasarkan hasil penelitian dari Imma Rachayu, Septian Jauhariansyah, dan Erlinda Juwita penelitian ini menjelaskan tentang manfaat metode drill and practice mampu meningkatkan aktivitas belajar siswa dengan efektif serta keaktifan pada indikatornya yaitu; fokus, aktif, memberi pertanyaan, memberi jawaban, kritikan, serta mendapatkan ide ataupun produktivitas pada tahap pembelajaran. Dapat dilihat dari hasil observasi yang didapatkan peneliti pada nilai persentase $82,5 \%$ yaitu berarti untuk implementasi dari metode drill and practice sudah dilaksanakan dengan (sangat baik) oleh karena itu mengalami peningkatan aktivitas belajar siswa yaitu 33\% yang didasarkan dengan hasil angket sebelum dan sesudah pemanfaatan metode tersebut. (Rachayu, Jauhariansyah, \& Juwita, 2020)

Dari hasil penelitian oleh Sutiah, dengan judul peningkatan hasil belajar siswa dengan metode drill di kelas V SD Negeri 165726 Tebing Tinggi tahun pelajaran 2013/2014 pada penelitian tersebut mendapatkan hasil yang positif untuk peningkatan hasil belajar peserta didik. Hal ini bisa terlihat pada peningkatan Hal peningkatan persentase pada tuntasnya belajar siswa pada siklus I (71,08 \%) dan siklus II (89,18\%). (Sutiah, 2016)

Dari hasil penelitian oleh Ari Lintang dan Indri Astuti, dengan judul pengembangan multimedia pembelajaran model drill and practice pada materi suhu dan kalor. Pada penelitian ini pengembangan yang telah dilakukan sudah menghasilkan multimedia pembelajaran model drill and practice. Dengan Konsep fisika tentang suhu dan kalor merupakan hal yang akan dibahas dalam multimedia ini. Multimedia ini bisa dapat dioperasikan secara baik oleh pengguna memakai perangkat seluler berbasis android. Model drill and practice merupakan kerangka tahapan pembelajaran yang implementasinya ke dalam multimedia. Latihan soal itu bisa dikerjakan dengan berulang kali bagi pengguna sampai mendapatkan nilai sesuai KKM yaitu 76.
Desain multimedia pembelajaran model drill and practice pada materi suhu dan kalor pada penggunaan model desain ADDIE. Struktur model desain ADDIE yang pergunakan yaitu model desain termodifikasi yaitu A-D-D-IE. Hasil validasi prototipe produk menghasilkan rata-rata validasi media 3,37 (sangat baik), 3,69 (sangat baik) dan 3,67 (sangat baik). Maka dari itu menghasilkan desain produk yaitu multimedia pembelajaran model drill and practice pada materi suhu dan kalor untuk Sekolah Menengah Pertama ini dikatakan pantas untuk di terapkan dalam pembelajaran.

Dari penelitian Abdulah, dan Muhammad Nur Wangid dengan judul Analisis kebutuhan multimedia interaktif berbasis drill and practice untuk meningkatkan motivasi dan keterampilan membaca kritis di sekolah dasar, pada hasil penelitian menunjukkan motivasi belajar siswa rendah yaitu tentang kemampuan membaca kritis dan motivasi belajar siswa ini mengakibatkan pada aktivitas pembelajaran harus mempunyai multimedia interaktif berbasis drill practice, serta tepatnya media pembelajaran, selanjutnya yaitu hasil analisis dalam penelitian kebutuhan media pembelajaran, peserta didik mengatakan memerlukan multimedia interaktif berbasis drill and practice. (Wangid, 2021)

Dari beberapa penelitian terdahulu penulis menyimpulkan sebagai berikut yaitu dengan penerapan model drill and practice dalam pelajaran matematika serta hitungan lainnya mampu memberi peningkatan hasil belajar siswa dengan begitu peneliti tertarik untuk menganalisis jurnal yang terkait dengan penerapan pembelajaran berbasis teknologi model drill and practice pada pelajaran matematika pada sekolah dasar. Yaitu apakah penggunaan pembelajaran berbasis teknologi model drill and practice ini mampu meningkatkan hasil belajar serta bagaimana implementasi model drill and practice dalam pembelajaran matematika disekolah dasar.

\section{METODE PENELITIAN}

Pada penelitian ini menggunakan metode kualitatif, pada analisis masalah yang terjadi dengan metode kualitatif menjadi sebuah cara dalam melaksanakan sebuah pencarian, pengamatan secara mendalam dengan tata cara ilmiah agar mendapatkan kesimpulan dalam kerangka pemaparan berdasarkan analisis data. Pendekatan pada penelitian ini merupakan library research, atau studi kepustakaan. Pendekatan ini juga mempunyai sumber dari artikel ilmiah, sera 
sumber dari internet atau kepustakaan. (Urip \& Maemonah, 2021) Pada penelitian ini data yang ada dihasilkan melalui teknik pengumpulan data dokumentasi yang sumbernya dari artikel-artikel ilmiah. Teknik memilih artikel cocok dengan permasalahan pada penelitian ini adalah artikel yang menganalisis tentang pembelajaran berbasis teknologi model drill and practice dalam pembelajran matematika di sekolah dasar. dengan menggunakan 6 artikel ilmiah yang peneliti analisis untuk menunjang penelitian kepustakaan ini.

\section{HASIL DAN PEMBAHASAN}

Pembelajaran dengan metode drill adalah metode pengajaran yang siswanya mengerjakan latihan-latihan dari pelajaran yang telah dipelajari oleh siswa sebelumnya dan juga sudah dijelaskan oleh guru, dari hasil analisis pada penelitian ini pemerolehan hasil yaitu tentang belajar peserta didik pada pembelajaran matematika, melalui pembelajaran yang berbasis teknologi pada penggunaan model drill and practice ini mendapatkan peningkatan untuk hasil yang signifikan yang sudah didapati bagi peserta didik misalnya keaktifan, perhatian, kehadiran serta berubahnya tingkah laku peserta didik pada pelajaran matematika pada implementasi metode drill and practice di dalam pembelajaran matematika, melalui metode ini sehingga peserta didik mampu terlatih mengahapi macammacam bentuk soal matematika, sehingga pesereta didik menjadi bersemangat dalam mempelajari materi yang diberikan guru.

Pada Implementasi metode pembelajaran ini diharapkan untuk meningkatkan penguasaan konsep matematika dan penumbuhan kreativitas siswa, dan peningkatan hasil belajar siswa sebelumnya mendapatkan hasil yang meningkat pesat. Pada penerapannya guru tidak hanya menggunakan model drill and practice saja namun bisa dikombinasikan dengan teknologi, contohnya audio visual seperti youtube, computer dll, sehingga dalam penerapan di sebuah pelajaran yang semulanya sulit dan monoton membuat siswa tertarik dan lebih aktif dari sebelumnya. Hasil yang meningkat ini dapat dilihat dari analisis jurnal oleh Wachid Nugroho jurnal dengan judul Pendekatan Inquiry Model Drill And Practice Berbasis Aplikasi Moodle Berbantuan Video Youtube Untuk Meningkatkan Aktivitas Dan Hasil Belajar Peserta Didik Pada Materi Limit Fungsi dengan menunjukan hasil meningkat menjadi $91,18 \%$ maka dengan implementasinya dari penelitian ini penulis tidak hanya mengunakan model drill and practice saja namun pada implementasinya selain menggunakan model drill and practice pada jurnal Wachid Nugroho juga menggunakan penunjang yang berbasis aplikasi moodle berbantuan video youtube.

Sementara penelitian oleh Farhanah, Artikel penelitian dengan judul tentang penggunaan metode drill terhadap hasil belajar matematika hitung campuran kelas III SDN 24 Pontianak. Pada penelitian ini meningkatkan hasil 71,81\%. Pada implementasinya peneliti menggunakan model drill and practice serta media yang disesuiakan oleh materi operasi hitung campuran, selanjutnya penelitian dari Imma Rachayu, Septian Jauhariansyah, dan Erlinda Juwita penelitian ini menjelaskan bahwa pemanfaatan metode drill and practice, pada hasil observasi yang di dapatkan peneliti yaitu persentase $82,5 \%$ yang maksudnya adalah penerapan metode drill and practice sudah diimplementasikan dengan "sangat baik" sehingga mendapatkan peningkatan aktivitas belajar siswa sebesar 33\% yang didasarkan pada hasil angket sebelum dan setelah pemanfaatan metode tersebut.

Selanjutnya pada penelitian oleh Sutiah, dengan judul peningkatan hasil belajar siswa dengan metode drill di kelas V SD Negeri165726 Tebing Tinggi tahun pelajaran 2013/2014 berdampak positif dalam meningkatkan hasil belajar siswa. Ini bisa terlihat pada peningkatan persentase ketuntasan belajar siswa pada siklus II $(89,18 \%)$, pada penelitian Ari Lintang dan Indri Astuti, dengan judul pengembangan multimedia pembelajaran model drill and practice pada materi suhu dan kalor. Hasil validasi prototipe produk menunjukan rata-rata validasi media 3,37 (sangat baik), 3,69 (sangat baik) dan 3,67 (sangat baik). Maka dari itu mendapatkan desain produk bebentuk multimedia pembelajaran model drill and practice pada materi suhu dan kalor untuk Sekolah Menengah Pertama pantas diterapkan.

Dari penelitian Abdulah, dan Muhammad Nur Wangid dengan judul Analisis kebutuhan multimedia interaktif berbasis drill and practice untuk meningkatkan motivasi dan keterampilan membaca kritis di sekolah dasar, dari hasil analisis dalam penelitian kebutuhan media pembelajaran, siswa menyatakan membutuhkan multimedia interaktif berbasis drill and practice, dengan penelitian menggunakan model drill and practice ini pada implementasinya didalam penelitian disarankan menggunakan media maupun yang berbasis teknologi audio visual dan 
lain sebagainya, pada implementasi menggunakan media maupun berbasis teknologi hasil dari analisis jurnal oleh Wachid Nugroho dan Farhanah sehingga siswa tidak merasa bosan ketika latihan yang diberikan oleh guru.

Pada model pembelajaran ini juga mempunyai kelebihan serta kekurangan didalam pelaksanaannya yang perlu di perhatikan oleh guru ketika hendak melaksanakan dengan penerapan model ini, pendapat Sudjana (2004:87) yaitu, petunjuk dan prinsip pada penggunaan metode Drill yaitu : 1) sebelum melaksanakan metode ini perlunya diberi pengertian yang mendalam kepada siswa seblum guru melaksanakan latihan tertentu, 2) pada latihan pertamanya guru perlu mendiangnosis, dari yang masih belum berhasil lalu diadakan sebuah perbaikan pada pertemuan selanjutnya bisa menjadi lebih baik, 3) pada tahap latihan disarankan tidak meski terlalu lama yang terpenting sering melakukan latihan secara berkala, 4) perlunya ada penyesuaian pada tingkat kemampuan siswa, 5) Proses latihan.

Kelebihan pada metode drill ini dalam pelajaran matematika siswa akan memiliki kemampuan berpikir yang baik berbentuk pemahaman serta penguatan atas konsep karena dengan pengajaran dalam metode ini siswa akan lebih terarahkan serta cermat dalam melaksanakan latihan-latihan.

\section{SIMPULAN DAN SARAN}

\section{A. Simpulan}

Hasil dari penelitian yang mengacu pada analisis 6 artikel jurnal yang membahas pengguaan model drill and practice dalam meningkatkan hasil belajar. Tujuan dari penelitian ini adalah untuk melihat penggunaan pembelajaran berbasis teknologi model drill and practice ini mampu meningkatkan hasil belajar, serta bagaimana implementasi model drill and practice dalam pembelajaran matematika pada proes pembelajaran. Pada penelitian ini dapat ditarik kesimpulan di atas yaitu pengunaan model drill and practice ini merupakan model pembelajaran yang dilakukan dengan melatih soal maupun pengulangan hapalan kosa kata, yang dilaksanakan dengan pengulangan-pengulangan agar menghasilkan keterampilan serta dibutuhkan agar mengingat secara matematis. Metode Drill and Practice pada penerapannya sangat cocok dalam pembelajaran hitungan, bahasa asing dan peningkatan perbendaharaan kata-kata serta pada model pembelajaran ini perlu diketahui bahwa model ini juga memiliki kelebihan serta kekurangan yang perlu diperhatikan oleh guru.

Pada implementasinya Sebelum pelajaran dilaksanakan pertama terlebih dahulu dengan pemberian pengertian dasar, perlunya masa latihan dilakukan dengan durasi singkat, agar tidak mendatangkan kejenuhan untuk peserta didik, selanjutnya Latihan diatur sedemikian rupa bisa menggunakan media maupun audio visual serta teknologi yang medukung materi yang dipelajari sehingga bersifat menarik dan dapat menimbulkan motivasi belajar anak sehingga dapat meningkatkan hasil belajar yang efektif.

\section{B. Saran}

Dari penelitian yang dilaksanakan, peneliti mengutarakan saran yaitu untuk pihak sekolah pertama guru, pembelajaran dengan metode drill and practice dapat mengutarakan sebagai pilihan model pembelajaran, karena dari hasil analisis penelitian terdahulu menghasilkan peningkatan untuk hasil belajar matematika, serta perlunya membentuk kondisi belajar yang mampu memberikan giliran kepada siswa untuk mengutarakan pendapat dengan cara mereka sendiri, sehingga siswa bisa berani berpendapat, lebih percaya diri, inovatif, serta media yang menarik membuat siswa tidak merasakan jenuh. Untuk peneliti yang ingin melaksanakan penelitian mendalam harus dilaksanakan penelitian tentang efek pembelajaran matematika dengan menggunakan metode drill and practice terhadap peningkatan hasil belajar matematika lainya. contohnya kemampuan penalaran, kemampuan komunikasi, kemampuan pemahaman dengan menggunakan pokok bahasan lainnya.

\section{DAFTAR RUJUKAN}

Adiwisastra, M. F. (2015). Perancangan Game Kuis Interaktif Sebagai Multimedia Pembelajaran Drill and Practice Untuk. Jurnal Informatika., II(1), 205-211. Retrieved from https://repository.widyatama.ac.id/xmlui/ bitstream/handle/123456789/9018/Bab 2.pdf?sequence $=10$

Farhanah. (2012). PENGGUNAAN METODE DRILL TERHADAP HASIL BELAJAR MATEMATIKA HITUNG CAMPURAN KELAS III SDN 24 PONTIANAK. Universitas Tajungpura.

Ismanto, E., \& Cynthia, E. P. (2017). Drill and 
Practice Model Dalam Pembuatan Media Pembelajaran Interaktif Pembentukan Objek Primitif Sederhana Dua Dimensi. Algoritma: Jurnal Ilmu Komputer Dan Informatika, 6341(Vol 1, No 01 (2017): November 2017), 18-23. Retrieved from http://jurnal.uinsu.ac.id/index.php/algorit ma/article/view/1304

Lintang, A., Astuti, I., \& Tanjungpura, U. (2021). PENGEMBANGAN MULTIMEDIA PEMBELAJARAN MODEL DRILL. 9(4), 508517.

Nasution Asrin, P. A. (2021). Analisis pembelajaran berbasis teknologi model dirll and practice untuk mi/sd. El-Midad: Jurnal PGMI, 13(1), 10-14.

Nasution, M. K. (2017). Penggunaan metode pembelajaran dalam peningkatan hasil belajar siswa. Studia Didaktika: Jurnal Ilmiah Bidang Pendidikan, 11(1), 9-16. Retrieved from http://jurnal.uinbanten.ac.id/index.php/stu diadidaktika/article/view/515/443

Nugroho Wachid. (2020). Pendekatan Inquiry Model Drill and Practice Berbasis Aplikasi Moodle Berbantuan Video Youtube untuk Meningkatkan Aktivitas dan Hasil Belajar Peserta Didik pada Materi Limit Fungsi. Jurnal Pendidikan MIPA, 10, 70-80.

Nurhasanah, S., \& Sobandi, A. (2016). Minat Belajar Sebagai Determinan Hasil Belajar Siswa. Jurnal Pendidikan Manajemen Perkantoran, 1(1), 128. https://doi.org/10.17509/jpm.v1i1.3264

Rachayu, I., Jauhariansyah, S., \& Juwita, E. (2020). PEMANFAATAN METODE DRILL AND PRACTICE PADA SUB POKOK CLASS DIAGRAM DALAM MENINGKATKAN. JDER Journal of Dehasen Education, 1(2), 98-103.
Surya, Y. F. (2017). PENERAPAN MODEL PEMBELAJARAN PROBLEM BASED LEARNING UNTUK MENINGKATKAN HASIL BELAJAR MATEMATIKA SISWA KELAS IV SDN 016 LANGGINI KABUPATEN KAMPAR Yenni Fitra Surya ?. Journal Cendekia: Jurnal Pendidikan Matematika, 1(1), 38-53.

Sutiah, S. (2016). Peningkatan Hasil Belajar Siswa Melalui Metode Drill Materi Operasi Hitung Bilangan Bulat Dan Pemecahan Masalah Pada Mata Pelajaran Matematika Di Kelas V Sdn 165726 Tebing Tinggi. Elementary School Journal Pgsd Fip Unimed, 5(1), 155164.

https://doi.org/10.24114/esjpgsd.v5i1.415 4

Urip, K. M., \& Maemonah. (2021). Analisis Hierarki Kebutuhan Maslow Dalam Pembelajaran Daring Anak Usia Dasar: Analisis Jurnal Sinta 2 Sampai 6. AULADUNA: Jurnal Pendidikan Dasar Islam, $8(1)$,

51. https://doi.org/10.24252/auladuna.v8i1a5. 2021

Wahyu, R., Putra, Y., Indriani, P., \& Info, A. (2017). Implementasi Etnomatematika Berbasis Budaya Lokal dalam Pembelajaran Matematika pada Jenjang Sekolah Dasar. Numerical: Jurnal Matematika Dan Pendidikan Matematika, 1(1), 9-14.

Wangid, Muhammad Nur, 'Needs Analysis of Interactive Multimedia Based on Drill and Practice to Improve Motivation and Critical Reading Skills in Elementary Schools', Jurnal Pendidikan, 6.3 (2021), 356-61 